\title{
Some Correlates of Academic Dishonesty among Undergraduates in Ogun State, Nigeria
}

\section{Algunas correlaciones de deshonestidad académica entre estudiantes universitarios en el estado de Ogun, Nigeria}

\author{
Williams, Taiwo M. \\ Babcock University, Ilishan Remo \\ Ogun State, Nigeria \\ Oyesoji Aremu \\ University of Ibadan, \\ Ibadan, Nigeria
}

(Rec: mayo de 2019 - Acept: noviembre de 2019)

\begin{abstract}
The purpose of this study is to examine some factors (Academic self-efficacy, motivation, Locus of control and gender) associated with academic dishonesty. 250 participants of both genders ( $76 \%$ men and $24 \%$ women) from 17 to 21 years old were selected using the purposive sampling technique. The instruments used were the General self-efficacy scale, the academic motivation scale, the locus of academic control scale and the academic dishonesty scale. The correlation coefficient, regression analysis, and t-tests were carried out. Academic self-efficacy, locus of control and motivation related to academic dishonesty. There was a gender difference on academic self-efficacy, locus of control and academic dishonesty. The results and implications are further discussed.
\end{abstract}

Keywords: Academic self-efficacy, academic dishonesty, locus of control, motivation

\section{Resumen}

El propósito de este estudio es examinar algunos factores (autoeficacia académica, motivación, lugar de control y género) asociados con la deshonestidad académica. Se seleccionaron 250 participantes de ambos sexos (76\% hombres y $24 \%$ mujeres) de edades comprendidas entre 17 y 21 años utilizando la técnica de muestreo intencional. Los instrumentos utilizados fueron la escala general de autoeficacia, la escala de motivación académica, la escala de locus de control académico y la escala de deshonestidad académica. Se realizaron coeficientes de correlación, análisis de regresión y pruebas t. Autoeficacia académica, locus de control y motivación relacionada con la deshonestidad académica. Hubo una diferencia de género en la autoeficacia académica, el lugar de control y la deshonestidad académica. Los resultados y las implicaciones se discuten más a fondo.

Palabras claves: Autoeficacia académica, deshonestidad académica, lugar de control, motivación 


\section{Introduction}

Academic dishonesty is undeniably perceived as a serious problem in higher education and it is neither confined to a particular region nor to a particular zone (Nwoye, Akpom \& Hwang, 2019; Rusdi, Hussein, Rahman, Noordin, \&Abd Aziz, 2019; International Center for Academic Integrity- ICAI, 2015) further defined academic dishonesty as a behavior or set of behaviors that led to the misrepresentation of scholarly work. This has also been viewed by several authors as a multifaceted and pervasive global phenomenon (Alleyne \& Phillips, 2011; Iberahim, Hussein, Samat, Noordin, \& Daud, 2013; Imran \& Nordin, 2013; Nazir \& Aslam, 2010; Saidin \& Isa, 2013; Tadesse \& Getachew, 2010; Thomas, 2017; Yang, Huang \& Chen, 2013). Sabli, Hamid, Haron and Wahab (2018) viewed academic cheating as polluting the future generations' ethical values and compromising the quality of the future workforce. Selemani, Chawinga and Dube (2018), stated that there was high prevalence of plagiarism, cheating and other forms of academic misconduct in higher education institutions and these forms of cheating may include, using or attempting to use unauthorized materials for class assignments or examinations; falsifying or inventing any type of information, including citations and references, on an assignment; copying other students' homework and assignments; cheating and plagiarism. Furthermore, Tadesse \& Getachew, (2010) stated that the consequence of academic dishonesty has been long-lasting in many occurrences and its impediment for growth is largely alarming. Cheating negatively impacts the educational factors and the students are the most affected by that; for example, students may come to the conclusion that those who cheat are more successful (Behroozi, Rafiee and Yakhchali, 2019). Earlier, Bretag (2013) observed that current research on academic integrity often focuses on impacts related to teaching and learning, particularly in institutions of higher education at the undergraduate level. The results of the study by Rusdi et al. (2019) on the academic dishonesty among Tertiary Students in Malaysia revealed that the most common form of academic dishonesty that students were involved in was plagiarism. Many reasons have been adduced to academic dishonesty among students. Some of these factors, as found in earlier studies, include: time-pressure; hard-courses; laziness; competition with others; coping with stress; difficultexams; minimal chances of getting caught; not serious punishments; improving one's grades; peer-pressure; fear of failure; "everybody does it"; course was useless; parents' pressure; taking a chance; lecturer does not care; low instructor-vigilance; high-course-load; not understanding questions; lack of effective study-habits; and negative attitudes (Chinamasa, Mavuru, Maphosa \&Tarambawamwe, 2011; Gesinde, Gbadebo \& Odusanya, 2011; Hussein, Rahman, Rusdi, Omar, \& Aziz, 2018). Many studies have also identified various methods by which academic dishonesty can be carried out. A study by Chinamasa et al. (2011) in Zimbabwe established that students cheat by using crib notes, which are smuggled into the examination room on body parts, clothing and materials used in the examination. Students also use silent cell phones to carry answer notes in the inbox and outbox modes. The findings were similar to those by Ali and Ali (2011) and Leopard (2017), which further showed that gestures and coordinated body language, like facial expression and hand -finger gestures, are commonly used in examination cheating by students. Since academic dishonesty is not a random, accidental or impulsive act according to Simkin and McLeod (2010) but a premedi- tated, intentional and deliberate act that requires forethought and planning, this study attempts to find out the factors that predict academic dishonesty among serial academically-frustrated students. Further literature review shows that little has been done in understanding the factors that predict academic dishonesty among serial academically-frustrated students.

According to Tenaw (2013), self-efficacy predicts intellectual performance better than skills alone and directly influences academic performance through cognition. Tenaw (2013) further stated that, although past performance raises self-efficacy, it is the student's interpretation of past successes and failures that may be responsible for subsequent success. Bandura (1997) defined self-efficacy as beliefs in one's capabilities to organize and execute the courses of action required to produce given attainment. Therefore, a student's academic self-efficacy refers to his or her perceptions or beliefs of the capability to learn, carry out and succeed in an academic task.

Individuals with high academic self-efficacy cope with complex incidents, overcome problems, are patient in their studies, more successful in their school and professional life and trust themselves to be able to accomplish (Korkmaz, 2011). According to Nora and Zhang (2010), there was an inverse relationship between self-efficacy and academic cheating. Reinforcement and vicarious learning are factors identified to help to increase self-efficacy related to specific behaviors (Smith, Burnett \& Wessel, 2017). Self-efficacy is a highly influential component to enhancing or inhibiting a behavior, as it is an individual's belief of successfully completing a task or behavior (Denler, Walters \& Benzon, 2014). Students' self-efficacy levels related to cheating may increase, as the behavior is reinforced through the lack of having to personally face a consequence or seeing others cheat without facing a consequence. This increased level of self-efficacy may then create a greater ease to continue the negative behavior (Smith, et al., 2017)

Locus of control in the study is described as a concept of the perceived control an individual has over his/her life and it could be internal or external (Rotter, 1990; Anastasi \& Urbina, 1997). Individuals with internal locus of control are believed to influence outcomes through their own abilities, efforts, or skills, while those with external locus of control believe that forces outside their control determine their outcomes, like luck, fate or powerful others (Rotter, 1990). Bvumbwe (2016) described locus of control as a dimension of personality which helps explain one's traits and behavior. Various research results put forth the idea that students with an internal locus of control generally use cognitive and metacognitive strategies more frequently, further test the development of their own knowledge and skills, and become more successful (Durna \& Senturk, 2012). Locus of control has also been described as a coping resource facilitating certain coping styles (Van den Brande, De Witte, Vander Elst \& Godderis, 2016). Alarape and Onakoya (2003) reported a significant negative relationship of locus of control with cheating behaviour. Their results also showed that individuals with external locus of control reported greater cheating. Engaging in academic dishonesty, or deliberate using someone else's information in a work submitted for academic credit, according to Sierra and Hyman (2006) likely depends somewhat on one's locus of control. In other words, believing that successes or failures are out of one's control may result in academic dishonesty. Those who cheat, as stated by Rettinger and Kramer (2009), tend to consider their be- 
haviour acceptable when they can describe it as caused by external forces rather than their own dishonesty. For instance, believing that an exam will be so difficult that it is impossible to pass may lead some students to engage in an academically dishonest behavior (i.e. cheating rather than studying).

In order to understand the influence of motivation on academic dishonesty, one can consider Deci and Ryan's (1991) self-determination theory. SDT is a macro theory of human motivation that has been successfully applied across domains including parenting, education, healthcare, sports and physical activity, psychotherapy, and virtual worlds, as well as the fields of work motivation and management (Ryan \& Deci, 2017). Moreover, Ryan and Deci (2019) further stated that Self-determination theory is a broad and widely applied theory of motivation, personality development, and wellness, a theory which began with a narrow focus on intrinsic motivation but has expanded over time to encompass both intrinsic and extrinsic motivations and spawned new perspectives on well-being, life-goals, relationship's quality, vitality and depletion, and eudaimonia, among other topics. Among the most crucial educational processes for students are acquiring new knowledge and skills while experiencing wellness and the desire to continue learning (Ryan \& Deci, 2016). Importantly, optimal teaching methods, which includes autonomy-supportive behaviors (for instance, taking students' internal frame of reference, offering choice, providing meaningful rationales for requested actions), can promote a variety of positive outcomes (Jang, Reeve, \& Halusic, 2016; Ryan \& Deci, 2016, 2017). Another critical component of SDT is the proposition that all human beings have three fundamental psychological needs, and their satisfaction is essential for autonomous motivation, wellness, and learning (Deci \& Ryan, 2000). One of the key distinctions within SDT is between autonomous motivation and controlled motivation. When autonomously motivated, people behave with a sense of willingness and volition, as they experience enjoyment or see personal value in the activity or behavior in which they are engaged. In contrast, when their motivation is controlled they behave with a sense of obligation and pressure from external sources (e.g., controlling rewards and punishments, which constitutes external regulation) and internal sources (e.g., guilt and contingent self-esteem, which constitutes introjected regulation), and they feel as though they have to do the activity or fulfill the behavior (Ryan \& Connell, 1989). Note that autonomous and controlled motivation differ from amotivation, which refers to a lack of desire or intention to engage in an activity. According to SDT, both autonomous and controlled types of motivation energize and direct behavior, but they result in different quality outcomes (Ryan \& Deci, 2016). Recent research showed that, when individuals set high standards for themselves, they tended to endorse mastery goals instead of performance goals, show greater self-determined motivation for school, achieve higher grades, cheat and procrastinate less, and show lower academic burnout (Bong, Hwang, Noh, \& Kim, 2014; Chang, Lee, Byeon, \& Lee, 2015; Harvey, Milyavskaya, Hope, Powers, Saffran, \& Koestner , 2015; Thorpe \& Netteelbeck, 2014). Self-determination theory claims individuals will experience the 'good life' if, and only if, their need for autonomy, relatedness, and competence is satisfied (Ryan \& Deci, 2018). Thus, societies that provide the conditions for need satisfaction provide the basis for a good society (Parker, Ryan, Duineveld \& Bradshaw, 2019).
Studies have been inconsistent and inconclusive in reporting gender differences and academic dishonesty. Malone (2006) reported that, although the attitude of male and female students differs on some dishonest acts, for most of the issues of dishonesty they behave in same way. Again, Cohen, Pant and Sharp (1998), in their study to evaluate the ethical evaluation and intention aspects of honest behaviors, found that males and females had significantly different set of judgments on their perception of ethical behaviour. Other studies (Davis, Grover, Becker \& McGregor, 1992; Lobel, 1993; Lobel \& Levanon, 1988) reported that males cheated more than females. Clariana, Badias and Cladellas (2013) while studying the Academic cheating and gender differences in Barcelona (Spain) found that boys cheat significantly more than girls in academic settings. This result was also found to be coherent with the findings of other studies (Honny, Gadbury-Amyot, Overman, Wilkins \& Petersen, 2010; Kobayashi \& Fukushima, 2012; Saulsbury, Brown, Heyliger \& Beale, 2011), stating that male students, probably because they do not build such strong ties with their social rules and environment as girls do, are more frequently involved in school fraudulent behaviors. It is evident from earlier studies that whether it is the males who cheat more or the females, there are definitely toxic ingredients responsible for such acts of dishonesty. Higher performers exerted more effort at difficult tasks, girls exerted more effort than boys for the same level of competence evaluation, and students who in general found school difficult evaluated their competence higher at easier tasks (Malmberg, Walls, Martin, Little \& Lim, 2013).

The objective of this study is therefore, to examine the joint influences of academic self-efficacy, locus of control, motivation; and gender on academic dishonesty of undergraduates in Ogun State, Nigeria.

The following research questions are answered in the study:

- What is the pattern of the relationship among the independent variables (academic self-efficacy, locus of control and motivation) and academic dishonety?

- What is the joint and relative contribution of the independent variables (academic self-efficacy, locus of control and motivation) to academic dishonesty?

- What gender difference will the independent variables (academic self-efficacy, locus of control and mo tivation) have on academic dishonesty?

\section{Method}

\section{Population and Sample}

The study was carried out in Ogun State, Nigeria. Ogun State is in Southwest Nigeria and its one of the 36 states in Nigeria. The state has three senatorial districts. Ogun State has Fifteen Universities in total (Eleven of these universities are owned by private). The population of the study was 8500 in five faculties of the institution in a private university. Two hundred and fifty undergraduates (190 males and 60 females) who had Cumulative Grade Point Average (CGPA) lower than 2.0 and attending an academic empowerment program at the institution were purposively selected for the study. These participants were in 2nd, 3rd or 4th year of their program at the university. Their ages ranged from 17 to 21 years with a mean age of 18.6 years. All questionnaires handed out to the participants were returned, thus giving a retrieval response rate of $100 \%$. 


\section{Instruments}

Academic Self-Efficacy.

The participants' academic self-efficacy was assessed using Schwarzer and Jerusalem (1995) General Self-Efficacy Scale. The 10 item scale was created to assess a general sense of perceived self-efficacy. Response items are rated on a 5-point Likert scale ranging from strongly disagree to strongly agree. It has a response format from very untrue to very true. Examples of items of the scale are: (1) I can always manage to solve difficult problems if I try hard enough (2) I can usually handle whatever comes my way. Cronbach alpha values of .76 and .90 were obtained for this study.

\section{Motivation.}

The Academic Motivation Scale (College version) by Vallerand, Blais, Briere and Pelletier (1989) was used to assess student motivations. This scale consists of 28 items which measures seven subtypes of motivation: intrinsic motivation (a) to know, (b) to accomplish, and (c) to experience stimulation; extrinsic motivation (a) external regulation, (b) introjection, and (c) identification; and amotivation. Response items are rated on a 5-point Likert scale ranging from strongly disagree to strongly agree. Examples of items on the scale are: (1) Because I think that a university education will help me better prepare for the career I have chosen and honestly, I don't know; (2) I really feel that I am wasting my time in school. Combined subscale scores indicate the extent to which a student is intrinsically, extrinsically, or amotivated in regard to his or her academic pursuits. For the current study, a Cronbach alpha value of 0.88 was obtained for this study.

Locus of Control.

The Academic Locus of Control Scale (ALOC) by Trice (1985) was adapted for the study. The scale consists of 28- items measured on a 5 point Likert scale ranging from strongly disagree to strongly agree. Examples of items on the scale are: (1) There are some subjects in which I could never do well (2) I consider myself highly motivated to achieve success in life. Cronbach alpha values of .80 and.79 were obtained for this study.

Academic Dishonesty.

Academic dishonesty was measured by adapting 15 items from the McCabe (2003) Kansas State University Academic
Dishonesty Survey Study. It has a response format from very untrue to very true. Examples of items on the scale include; (1) I turn in work done by someone else; (2) I help someone else cheat on a test. The items measured on a 5 point Likert scale ranging from strongly disagree to strongly agree. The instrument was revalidated to suit the circumstances of the participants in this study. A Cronbach alpha value of .88 was obtained for this study.

\section{Procedure}

The participants of this study were students on academic probation for poor academic results. The method of selection was, therefore, purposive so as to include all students who have enrolled and spent a minimum of one academic semester (4 months) in the academic empowerment program. Permission was sort from the school counselors and teachers assigned to teach in the academic empowerment program. The participants were allowed to go with the questionnaires and return them after completion.

\section{Data Analysis}

Pearson Product Moment Correlation was used to determine the relationship among the variables, while multiple regression analysis was used to determine the combined and relative effects of the independent variables to the dependent variable, and T-test was used to obtain the gender difference among the variables.

\section{Results}

In order to know the relationship among the variables, Table 1 presents a bivariate correlational analysis, which showed the significant correlation between the independent variables and the dependent variable. Locus of control $(r=.316 ; P<.005)$ showed significant positive relationships with academic dishonesty. This may imply that the participants who exhibit a high level of locus of control, will yield a decrease in academic dishonesty. Again, academic self-efficacy $(r=-.392 ; P<.005)$ and motivation $(r=-.113 ; P<.005)$ showed a negative correlation with academic dishonesty. This implies that, when there is a decrease in academic self-efficacy and motivation, there would be an increase in academic dishonesty.

Table 1. Correlation coefficient among variables

\begin{tabular}{|c|c|c|c|c|c|c|}
\hline Variables & Mean & $\begin{array}{l}\text { Standard } \\
\text { Deviation }\end{array}$ & $\begin{array}{l}\text { Academic } \\
\text { Dishonesty }\end{array}$ & $\begin{array}{l}\text { Academic } \\
\text { Self-efficacy }\end{array}$ & Locus of control & Motivation \\
\hline Academic Dishonesty & 20.31 & 6.78 & 1.000 & $-.392^{*}$ & .316 & -.113 \\
\hline Academic Self-efficacy & 144.38 & 25.16 & -.392 & 1.000 & -.057 & $.134^{*}$ \\
\hline Motivation & 33.45 & 4.95 & -.113 & .134 & $-.157^{*}$ & 1.000 \\
\hline
\end{tabular}

*significant at.05 level 
Table 2 shows the composite of the independent variables which when put together as a composite construct yielded a coefficient of multiple regression (R) of .786 and a multiple correlation square (R2) of .615. This shows that $61.5 \%$ of the total variance in academic dishonesty of the students is accounted for the combination of the three independent variables. The analysis of variance showed an F-ratio value significant at .05 level, $\left(F 3,24^{6}=4.348 ; p<.05\right)$. This result further confirms that academic self-efficacy, locus of control and motivation have an influence on academic dishonesty of the undergraduates.
Table 2 also shows the relative influence of the independent variables on academic dishonesty. The variables contributed in terms of magnitude as follows: motivation, $\beta=.081, t=9.766$, $p<.05$; locus of control, $\beta=.101 ; t=6.406, p<.05$ and academic self-efficacy, $\beta-=.077 ; t=6.336, p<.05$

Table 2. Summary of Regression Analysis between the Independent Variables and Academic Dishonesty $(R=.786 ; R 2=.615 ;$ Adj $R 2=.603$; Standard Error Estimate =6.732)

\begin{tabular}{|c|c|c|c|c|c|}
\hline Source of variation & Df & Sum of squares & Mean square & F-ratio & $\mathrm{p}$ \\
\hline Regression & 3 & 1340.462 & 223.411 & 4.348 & 05 \\
\hline Residual & 246 & 8987.896 & 35.980 & & \\
\hline \multirow[t]{2}{*}{ Total } & 249 & 10328.368 & & & \\
\hline & $\begin{array}{l}\text { Unstandardized } \\
\text { coefficient } \\
\text { B }\end{array}$ & $\begin{array}{l}\text { Standardized } \\
\text { coefficients } \\
\text { SEB }\end{array}$ & & $\begin{array}{l}\mathrm{t} \\
\text { Beta }(\beta)\end{array}$ & Significance \\
\hline Constant & 30.26 & 6.310 & & 5.360 & 000 \\
\hline Academic self-efficacy & 0.111 & 0.016 & 0.077 & 6.336 & 001 \\
\hline Motivation & 0.052 & 0.005 & 0.081 & 9.766 & 000 \\
\hline Locus of control & 1.113 & 0.173 & 0.101 & 6.406 & 001 \\
\hline
\end{tabular}

$p<.05$

Table 3 shows significant gender difference in the academic Self-efficacy, locus of control, motivation and academic dishonesty of the participants. There were significant gender differences in the academic self-efficacy, locus of control and academic dishonesty of these students while showing no significant difference in their Motivation. Considering the fact that more males registered into this academic empowerment program as a result of very poor grades might mean that academic self-efficacy and locus of control of male students was low compared to females; whereas what motivates both males and females into academic dishonesty is quite similar.

Table 3. T-test analysis showing gender difference of the independent variables and academic dishonesty among serial academically frustrated students

\begin{tabular}{lllllll}
\hline & Gender & $\mathrm{N}$ & Mean & $\begin{array}{l}\text { Std. } \\
\text { Deviation }\end{array}$ & df & Sig. \\
\hline Academic self-efficacy & Male & 209 & 0.1005 & 1.30622 & 249 & 7.138 \\
& Gender & 41 & -1.5366 & 1.51818 & 000 \\
Locus of control & Male & 209 & -1.3876 & 1.55910 & -1.589 & 000 \\
\multirow{2}{*}{ Motivation } & Female & 41 & -1.0000 & 0.0000 & 0.618 \\
\multirow{2}{*}{ Academic Dishonesty } & Male & 209 & -0.4019 & 1.11855 & 537 \\
& Female & 41 & 0.5122 & 0.50606 & 5.452 \\
& Male & 209 & 0.3011 & 1.31722 & 000 \\
\hline
\end{tabular}

\section{Discussion}

The findings of the study showed that academic self-efficacy and motivation has a negative relative relationship to academic dishonesty, thus indicating that when academic self-efficacy and motivation towards success is low, then there will be a rise in academic dishonesty and when it is high, acade- mic dishonesty will reduce. Many of the students in this study reported that when failing once or twice in their academics, they lose motivation and belief for wanting to continue and may as well just look for easy ways by which better grades could be obtained. Earlier studies conducted in the last ten years also suggested direct links between self-efficacy, academic achievement and academic performance (Mustafa, 
Esma, \& Ertan, 2012; Reid, 2013; Tolliver, \& Miller, 2018). This was further corroborated by the data analysis from a study of African American male student graduate success: an exploration of self-efficacy, motivation, and persistence by Forster (2019) which revealed that mastery experiences, verbal persuasion, and vicarious experiences enhanced self-efficacies of the participants. This again is supported by Bandura (2006) who noted that students who exhibit high self-efficacy believe that they can accomplish much in their studies while those with low self-efficacy beliefs are usually unsure of what they can achieve or may not even believe that they can succeed in a given task, thus, they try to avoid such situations and may give up completely once they encounter failure. (Baker, 2004) found that intrinsic motivation contributes positively to learning, while extrinsic motivation impairs learning, resulting in poorer performance and increased need to cheat. It further indicates that those who are externally motivated to obtain good grades and, escape failure, may see the potential for gain by engaging in dishonesty, while those who are intrinsically motivated by a desire to learn and be successful in a given task would stay away from dishonest behaviors. According to SDT, when people's basic psychological needs are satisfied, the individuals are likely to be autonomously motivated, and more positive outcomes are likely to follow. However, when people's needs are frustrated, they are more likely to experience controlled motivation as well as relatively negative outcomes (Ryan \& Deci, 2017). In short, the distinction between need satisfaction and need frustration according to Ryan \& Deci, 2017; Vansteenkiste \& Ryan, 2013, is crucial because these two different experiences are related to different motivations and outcomes. In this case, the need to succeed is important to the students and it is a need that must be met. When the students feel that they are not achieving anything, this may result into academic dishonesty. A further research on the Path analytic study of effect of motivation and learning behaviour on student achievement indicated that intrinsic motivation indirectly influenced learning achievement through learning behaviour, some of which may include habits of attending college, visiting the library, readiness to take the exam, as well as frequency of accessing the internet (Tokan \& Imakulata, 2019).

Locus of control also showed a positive correlation to academic dishonesty. Alias, Akasah, Kesot (2012) indicate that students tend to have internal locus of control rather than external locus of control; and that the internal students have above average level in self-efficacy and positive attitudes, with female students having stronger positive attitude compared to male students. A relationship between locus of control and academic dishonesty has been found among average ability samples, whereby those with an external locus of control are more likely to engage in academic dishonesty than those with an internal locus of control (Gallagher, 2010; Rettinger \& Kramer, 2009). Those students with an internal locus of control had above average college course grades and greater academic success overall (Carden, Bryant, \& Moss, 2004; Keith, Pottebaum \& Eberhardt, 1986; Kirkpatrick, Stant, Downes \& Gaither, 2008). Moreover, when college students move from an external to an internal locus of control, their grades tend to improve (Noel, Forsyth, \& Kelley, 1987). Coleman and Mahaffey (2000) found similar results which showed that those with an external locus of control viewed cheating as more acceptable than those with an internal locus of control.
Basol and Turkoglu (2009); Yalcin, Tetik, and Acikgoz (2010) also noted that, while all these findings in their research put forth the possession of internal locus of control as a positive personality trait, they also put forth that possessing external locus of control depicts a negative situation. This was further strengthened by Nejati, Abedi, Agbaci and Mohammadi (2017); Nongtdu \& Bhutia (2017) in their study found that there was a strong positive correlation between internal locus of control and academic achievement among college students from different streams, in both genders, from colleges of both the locale. Fini \& Yousefzadeh (2011) found that educational achievement, motivation and locus of control are related to each other, since high level of achievement motivation leads to increasing level of educational achievement, and an increase in educational achievement leads to increasing the level of achievement motivation. On the other hand, internality of the locus of control leads to increasing of achievement motivation and vice versa.

Further, the study indicated significant gender differences in the academic self-efficacy, locus of control and academic dishonesty of these students while showing no significant difference in their motivation. However, Anita and Jebaseelan (2018) found a significant difference between the gender and the overall achievement motivation score, but Malone (2006) had earlier reported that, though the attitude of male and female students differ on some dishonest acts, for most of the issues of dishonesty they behave in same way. More recently, the results of the study on snapshot of academic dishonesty among Malaysian nursing students: a single university experience carried out by Ali, Nurhanis, Dariah and Mohd (2018) indicated that there is a statistically significant relationship between gender and academic dishonesty in clinical settings, in that male students reported having engaged in clinical dishonesty more than female students. This was consistent with Ballantine, Larres and Mulgrew (2014) who earlier inferred from the socialization theory that females are more likely to follow rules than males, thus finding a consistency with the study conducted among the accounting students in Malaysia, which showed that male students were less likely to follow rules than female students (Ismail \& Yussof, 2016). Faizah, Asadi and Mokhtar (2016) found female respondents in their study to have higher intrinsic motivation than their male counterparts. Thus, supporting the submission of this current study that females believed they perhaps have not put enough effort in their studies, thus resulting in repeated failures, and that extra efforts would bring about success rather than getting involved in academic dishonesty. Whereas the males believe it is due to that some of their teachers do not like them and see them as never- do-wells, thus resulting in their continuous failures and which could probably propel them into academic dishonesty as a means of succeeding.

The students who took part in this study were beneficiaries of the new dimension to helping students improve in their academic performance. This is because the university believes that sending the students out of the university when they fall below the expected academic standard may not be the best option, rather than assisting them to understand and identify various personal, social and behavioural issues that may be militating against their excellent academic performances while in school. This study has shown the need for teachers and stake holders to encourage character strength and development among the students who are academic dishonesty as a result 
of constant failure in classes over time. This is on the grounds that good character strength can be associated with positive classroom behavior which eventually leads to successful academic achievement. Encouraging students to develop some form of phasic strength in terms of bravery and hope to endure the storm of failure without resulting into academic dishonesty is of great importance. Apart from counseling the students, the study also suggests that parents are to be assisted with understanding their expectations, because most of the time the high unrealistic expectations of parents can push students who have fell into various academic mischiefs and frustrate them further in exhibiting dishonesty. More universities should be encouraged to follow the pattern of understanding the factors that may militate the expected academic performance of their students, by seeking or asking them to seek help of trained counselors, since school counselors are saddled with the responsibility of nurturing the healthy development of all students rather than the position of suspension or outright withdrawal sanctions by the Institutions. There is the need for the inclusion of ethics in the undergraduate curriculum for all students by policy makers and educators. In light of the above, the counseling centers in institutions should be equipped with qualified personnel to assist students in developing and improving upon the traits discussed in this study. The study found more males than females registered in the program, perhaps further studies on the topic may identify reasons why this is so.

\section{References}

Alarape, A. \& Onakoya, A. (2003). Correlates of examination cheating behavior among university students. IFE Psychologia: An International Journal, 11(1), 71-79.

Ali, S. \& Ali, M. (2011). The use of non-verbal communication in the classroom. Paper presented at the First International Conference on Foreign Language Teaching and Applied Linguistics, Sarajevo. Retrieved from https://pdfs.semanticscholar.org/9c8f/2332 8de9af2e68342092f5ffaeac89769bf2.pdf

Ali, H., Nurhanis, Z., Dariah, Y. \& Mohd, Z. (2018). Snapshot of academic dishonesty among Malaysian nursing students: A single university experience. Journal of Taibah university Medical Sciences, 13 (4), 370-376.

Alias M, Akasah, Z. \& Kesot, M. (2012). Self-efficacy, locus of control and attitude among engineering students: Appreciating the role of affects in learning efforts. Procedia-Social Behavioural Sciences, 56, 183-190.

Alleyne, P. \& Phillips, K. (2011). Exploring academic dishonesty among university students in Barbados: an extension to the theory of planned behaviour. Journal of Academic Ethics, 9(4), 323-338.

Anastasi, A. \& Urbina, S. (1997). Psychological testing. Upper Saddle River, NJ: Prentice Hall.

Anita, P. \& Jebaseelan, S. (2018). Study on Achievement Motivation among Adolescent Students in Colleges of Trichirappalli District. Journal of Humanities and Social Science, 1(6), 25-31.

Baker, J. (2004). An investigation of relationships among instructor immediacy and affective and cognitive learning in the online classroom. The Internet and Higher Education, 7(1), 1-13,

Ballantine, J., McCourt Larres, P. \& Mulgrew, M. (2014). Determinants of academic Cheating behavior: the future for accountancy in Ireland. Accounting Forum,
38(1), 55-66.

Bandura, A. (1997). Self-efficacy: The exercise of control. New York: Freeman.

Bandura, A. (2006). Toward a psychology of human agency. Perspectives on Psychological Science, 1, 164-180.

Basol, G. \& Turkoglu, E. (2009). The relationship between the locus of control and thinking styles of teacher candidates. International Journal of Human Sciences, 6(1), 732-757

Behroozi, N., Rafiee, Z. \& Haji Yakhchali, A. (2019). Predictors of Exam Cheating Among the High School Students: Role of Personality Characteristics, Sensation-Seeking, Locus of Control and Exam Anxiety. Iranian Evolutionary and Educational Psychology, Journal, 1(1), 24-33.

Bretag, T. (2013). Challenges in Addressing Plagiarism in Education. PLoS Med, 10(12), e1001574.

Bong, M., Hwang, A., Noh, A. \& Kim, S. (2014). Perfectionism and motivation of adolescents in academic contexts. Journal of Educational Psychology, 106(3), 711-729.

Bvumbwe, T. (2016). Enhancing nursing education via academic clinical partnership: an integrative review. International journal of nursing sciences, 3(3), 314 $-322$.

Carden, R., Bryant, C. \& Moss, R. (2004). Locus of control, test anxiety, academic procrastination, and achievement among college students. Psychological Reports, 95(2), 581-582.

Chang, E., Lee, A., Byeon, E. \& Lee, S. (2015). Role of motivation in the relation between perfectionism and academic burnout in Korean students. Personality and Individual Differences, 82, 221-226.

Chinamasa, E. Mavuru, L., Maphosa C. \& Tarambawamwe, P. (2011) Examination cheating, exploring strategies and contributing factors in Universities in Zimbabwe. Group Journal, 1(1), 1-23.

Clariana, M., Badias, M. \& Cladellas, R. (2013) Academic cheating and gender differences in Barcelona (Spain). Summa Psicológica UST, 10(1), 65-72.

Cohen, J., Pant, L., \& Sharp, D. (1998). The Effect of Gender and Academic Discipline Diversity on the Ethical Evaluations, Ethical Intentions and Ethical Orientation of Potential Public Accounting Recruits. Accounting Horizons, 12(3), 250-270.

Coleman, N., \& Mahaffey, T. (2000). Business student ethics: Selected predictors of attitudes toward cheating. Teaching Business Ethics, 4(2), 121-136.

Davis, S., Grover, C., Becker, A. \& McGregor, L. (1992). Academic dishonesty: Prevalence, determinants, techniques, and punishment. Teaching of Psychology, 19(1), 16-20.

Deci, E. \& Ryan, R. (1991). A motivational approach to selfIntegration in personality. In R.Dienstbier (Ed.), Nebraska symposium on motivation: Perspectives on motivation (pp. 237-288). Lincoln: University of Nebraska Press.

Deci, E. \& Ryan, R. (2000). The 'what' and 'why' of goal pursuits: human needs and the Self-determination of behavior. Psychological Inquiry, 11(4), 227-268.

Denler, H., Walters, C. \& Benzon, M. (2014). Social Cognitive Theory. Retrieved from: http://www. education. com/reference/article/social-cognitive-theory/

Durna, U. \& Senturk, F. (2012). A study to determine the locus 
of control of university students with the contribution of different variables. Zonguldak Karaelmas University Journal of Social Sciences, 8(15), 37-48.

Faizah, I., Asadi, Z., \& Mokhtar, N. (2016) Academic Dishonesty and Achievement Motivation: A Delicate Relationship. Higher Education of Social Science, 11(1), 1-8.

Fini, A. \& Yousefzadeh, M. (2011). Survey on Relationship of Achievement Motivation, Locus of Control and Academic Achievement in High School Students of Bandar Abbas (Iran). Procedia - Social and Behavioral Sciences, 30(1), 866-870.

Forster, S. (2019). African American Male Student Graduate Success: An Exploration Of Self-Efficacy, Motivation and Persistence. A Dissertation Presented in Partial fulfilment Of the Requirements for the Degree Doctor of Philosophy, Capella University. 136 Pp. https://search.proquest.com/openview/fa29c b1b4e12e7d343306ca1b8a9c324/1?pq-origsite=gs cholar \&cbl=18750\&diss $=y$

Gallagher, J. (2010). Academic integrity and personality (Unpublished Master's thesis). California State University: Long Beach, CA. Retrieved from http://citeseerx.ist.psu.edu/viewdoc/download?doi=10.1.1.45 7.3429\&rep $=$ rep $1 \&$ type $=p d f$

Gesinde, A., Adejumo, G. \& Odusanya, T. (2011). Forms of Academic Cheating During Examination among Students with Hearing Impairment in Nigeria: Implication for Counseling Practice, European Journal of Social Sciences, 26 (2), 276-286.

Harvey, B., Milyavskaya, M., Hope, N., Powers, T., Saffran, M. \& Koestner, R. (2015). Affect variation across days of the week: Influences of perfectionism and academic motivation. Motivation and Emotion, 39(4), 521-530.

Honny, J., Gadbury-Amyot, C., Overman, P., Wilkins, K., \& Petersen, F. (2010). Academic integrity violations: A national study of dental hygiene students. Journal of Dental Education, 74 (3), 251-260.

Hussein, N., Rahman, N., Rusdi, S., Omar, M., \& Aziz, Z. (2018). Factors that Influence Self-Perceived Academic Cheating: An Empirical Evidence of Business Students. International Journal of Academic Research in Business and Social Sciences, 8(11), 758-767.

Iberahim, H., Hussein, N., Samat, N., Noordin, F. \& Daud, N. (2013). Academic dishonesty: why business students participate in these practices? ProcediaSocial and Behavioral Sciences, 90, 152-156.

Imran, A. \& Nordin, M. (2013). Predicting the underlying factors of academic dishonesty among undergraduates in public universities: a path analysis approach. Journal of Academic Ethics, 11(2), 103-120. International Center for Academic Integrity. (2015). The fundamental values project: Clemson, SC: Clemson University Press. Retrieved from http://www. academicintegrity.org,

Ismail, S. \& Yussof, S. (2016). Cheating behaviour among accounting students: some Malaysian evidence. Accounting Research Journal, 29 (1), 20-33.

Jang, H., Kim, E. \& Reeve, J. (2016). Why students become more engaged or more disengaged during the semester: A self-determination theory dual-process model. Learning and Instruction, 43, 27-38.

Keith, T., Pottebaum, S. \& Eberhardt, S. (1986). Effects of selfconcept and locus of control on academic achie- vement: A large-sample path analysis. Journal of Psychoeducational Assessment, 4(1), 61-72.

Kirkpatrick, M., Stant, K., Downes, S. \& Gaither, L. (2008). Perceived locus of control and academic performance: Broadening the construct's applicability. Journal of College Student Development, 49(5), 486-496.

Kobayashi, E., \& Fukushima, M. (2012). Gender, social bond, and academic cheating in Japan. Sociologial Inquiry, 82 (2), 282-304.

Korkmaz, I. (2011). Eğitim psikolojisi (Educational psychology). In B. Yeşilyaprak (Ed.), Sosyal öğrenme kuramı (Social learning theory) (pp. 245-269). Ankara: Pegem A Pub.

Leopard, J. (2017). Language and cheating in Higher Learning Education examinations- A Case Study of the Open university of Tanzania. European Journal of Foreign Language Teaching, 2(2), 20-32.

Lobel, T. \& Levanon, T. (1988). Self-esteem, need for approval and cheating behavior in Children. Journal of Educational Psychology, 80(1), 122-123.

Lobel, T. (1993). Gender differences in adolescents' cheating behavior: An interactional model. Personality Individual Differences, 14(1), 275- 277.

Malmberg. L., Walls, T., Martin, A., Little, T. \& Lim, W. (2013). Primary school students' learning experiences of and self-beliefs about competence, effort, and difficulty: Random effects models. Learning and Individual Differences, 28, 54-65.

Malone, F. (2006). The ethical attitude of accounting students. Journal of American Academy of Business Cambridge, 8(1), 142-146

McCabe, D. (2003). Spring Semester Kansas State University Academic Dishonesty Survey Study. Retrieved from http://www.k-state.edu/honor/ research links/mccabesurvey2003/survey03.htm.

Mustafa, M., Esma, C. \& Ertan, Z. (2012). The relationship between self-efficacy and academic performance. Social and Behavioral Sciences, 46, 1143-1146.

Nazir, M. \& Aslam, M. (2010). Academic dishonesty and perceptions of Pakistani students. International Journal of Educational Management, 24(7), 655-668.

Nejati, M., Abedi, A. Aghaci, A. \& Mohammadi, M. (2017). The Relationship between locus of control with the academic performance of the M.A. Students by considering the Role of Life Quality and Satisfaction with life. Interdisciplinary Journal of Contemporary Research in Business, 4(5), 254-263.

Noel, J., Forsyth, D. \& Kelley, K. (1987). Improving the performance of failing students by overcoming their self-serving attributional biases. Basic and Applied Social Psychology, 8(1-2), 151-162.

Nongtdu, S. \& Bhutia, Y. (2017) Locus of Control in Relation to Academic Achievement of College Students in Meghalaya. Paper presented at the Fourth International Conference on Multidisciplinary Research \& Practice, Ahmedabad, Gujarat, India. Retrieved from https://www.rsisinternational.org/ conference/4ICMRP2017/papers/159-165.pdf

Nora, W. \& Zhang, K. (2010). Motives of cheating among secondary students: The role of self-efficacy and peer influence. Asia Pacific Education Review, 11(4), 573-584.

Nwoye, Y., Akpom, U. \& Hwang, J (2019). Students Attitude and 
Perceptions towards Academic Dishonesty. Journal of Education \& Social Policy, 6(1), 114-131.

Parker, P., Ryan, R., Duineveld, J. \& Bradshaw, E. (2019). Validation of the social identity group need satisfaction and frustration scale. doi.org/10.31234/osf.io/ ycbwe

Reid, K. (2013). Understanding the relationship among racial identity, self-efficacy, institutional integration and academic achievement of black males attending research universities. Journal of Negro Education, 82(1), 75-93.

Rettinger, D. \& Kramer, Y. (2009). Situational and personal causes of student cheating. Research in Higher Education, 50(3), 293-313.

Rotter, J. (1990). Internal versus external control of reinforcement: A case history of a variable. American Psychologist, 45(4), 489-493.

Rusdi, S., Hussein, N., Rahman, N., Noordin, F. \& Aziz, Z. (2019) Academic Dishonesty among Tertiary Students in Malaysia. International Journal of Academic Research in Business and Social Sciences, 9(3), 512520.

Ryan, R. \& Connell, J. (1989). Perceived locus of causality and internalization: Examining reasons for acting in two domains. Journal of Personality and Social Psychology, 57, 749-761.

Ryan, R. \& Deci, E. (2000). Intrinsic and extrinsic motivations: Classic definitions and new directions. Contemporary Educational Psychology, 25(1), 54-67.

Ryan, R. \& Deci, E. (2016). Facilitating and hindering motivation, learning, and well- being in schools. In K. R. Wentzel, \& D. Miele (Eds.), Handbook of motivation at school (pp. 96-119). New York: Routledge.

Ryan. R. \& Deci, E. (2017). Self-Determination Theory: Basic Psychological Needs in Motivation, Development, and Wellness. New York: Guilford.

Ryan, R. \& Deci, E. (2018). Self-determination theory. New York: Guilford Publications.

Ryan, R. \& Deci, E. (2019). Brick by brick: The origins, development, and future of self- determination theory. In A. J. Elliot (Ed.), Advances In motivation science, pp. 111-156. Cambridge, MA.: Elsevier.

Sabli, N., Hamid, N., Haron, N. \& Wahab, R. (2018). Academic Cheating Among Undergraduate Accounting Students: Fraud Diamond Theory Perspective. National Academy of Managerial Staff of Culture and Arts, 1, 932-937.

Saidin, N. \& Isa, N. (2013). Investigating Academic Dishonesty among Language Teacher Trainees:The Why and How of Cheating. Procedia-Social and Behavioral Sciences, 90, 522-529.

Saulsbury, M., Brown, U., Heyliger, S. \& Beale, R. (2011). Effect of dispositional traits on Pharmacy students' attitude towards cheating. American Journal of Pharmaceutical Education, 75(4), 1-8.

Schwarzer, R. \& Jerusalem, M. (1995). Generalized Self-Efficacy scale. In J. Weinman, S.

Wright, \& M. Johnston, Measures in health psychology: A user's portfolio. Causal and control beliefs (pp. 3537). Windsor, UK: NFER-NELSON.

Selemani, A., Chawinga, W. \& Dube, G. (2018) Why do postgraduate students commit plagiarism? An empirical study. International Journal for Educational Integrity, 14(7). 1-15.
Sierra, J, \& Hyman, M. (2006) A Dual-Process Model of Cheating intentions. Journal of Marketing Education, 28(3), 193-204.

Simkin, M. \& McLeod, A. (2010). Why do College Students Cheat? Journal of Business Ethics, 94(3), 441-453.

Smith, T., Burnett, A. \& Wessel, M. (2017), Use of the Social Cognitive Theory to Explain Cheating in College: Implications for Future Health Professionals. Health Educator, 49(2), 1-9.

Tadesse, T. \& Getachew, K. (2010). An exploration of undergraduate students' self-reported academic dishonesty at Addis Ababa and Jimma Universities. Ethiopian Journal of Education and Sciences, 5(2), 77-99.

Tenaw, Y. (2013). Relationship between self-efficacy, academic achievement and gender in analytical chemistry at DebreMarkos College of teacher education. African Journal of Chemical Education, 3(1), 3- 28.

Thomas, D. (2017). Factors that explain academic dishonesty among University Students in Thailand. Ethics \& Behavior, 27(2), 140-154.

Thorpe, E. \& Netteelbeck, T. (2014). Testing if healthy perfectionism enhances academic achievement in Australian secondary school students. Journal of Educational and Developmental Psychology, 4(2), 1-9.

Tokan, M. \& Imakulata, M. (2019) The effect of motivation and learning behaviour on student achievement. South African Journal of Education, 39(1), 1-8.

Tolliver, D. \& Miller, M. (2018). Graduation 101: Critical strategies for African American men college completion. Education, 138(4), 301-308.

Trice, A. (1985). An academic locus of control scale for college students. Perceptual and Motor Skills, 61(3), 10431046.

Vallerand, R., Blais, M., Brière, N. \& Pelletier, L. (1989). Construction et validation de l'échelle de motivation en éducation (EME) [Construction and validation of the Motivation toward Education Scale]. Canadian Journal of Behavioural Science / Revue canadienne des sciences du comportement, 21(3), 323-349.

Vansteenkiste, M. \& Ryan, R. (2013). On psychological growth and vulnerability: Basic psychological need satisfaction and need frustration as a unifying principle. Journal of Psychotherapy Integration, 23(3), 263-280.

Van den Brande W., Baillien E., De Witte H., Vander Elst T. \& Godderis L. (2016). The role of work stressors, coping strategies and coping resources in the process of workplace bullying: a systematic review and development of a comprehensive model. Aggression and Violent Behavior, 29, 61-71.

Yalcin, B., Tetik, S. \& Acikgoz, A. (2010). A study on the determination of the perceptions of problem solving skills and the levels of locus of control of high school students. Organizasyon ve Yönetim Bilimleri Dergisi, 2(2), 19-27.

Yang, S., Huang, C. \& Chen, A. (2013). An investigation of college students' perceptions of academic dishonesty, reasons for dishonesty, achievement goals, and willingness to report dishonest behavior. Ethics \& Behavior, 23(6), 501-522. 